\title{
İstanbul'a Yönelik İç Göç Hareketlerinin Ekonometrik Analizi
}

\author{
HAMDI EMEÇ* \\ hamdi.emec@deu.edu.tr \\ ORCID ID: 0000-0001-6348-5794
}

\author{
ŞENAY ÜÇDOĞRUK BIRECIKLI*** \\ s.ucdogruk@deu.edu.tr \\ ORCID ID: 0000-0002-5842-4012
}

\author{
BURCU KÜMBÜL GÜLER*** \\ burcu.guler@ikcu.edu.tr \\ ORCID ID: 0000-0002-6179-7557
}

Öz: Aldığı göç ile çekici bir göç destinasyonu olarak Türkiye’nin en fazla nüfusuna sahip olan İstanbul göç araştırmalarının ilgi odağını oluşturmaktadır. Bu çalışmanın amacı İstanbul'a göç edenlerin; köy, ilçe ve il düzeyinde, kim olduğunu, sosyo-demografik faktörler açısından ortaya koymaktır. Araştırmada Türkiye İşgücü Araştırması 2015 ham verilerinden yararlanarak İstatistiki Bölge Birimleri Sınıflamasından İstanbul verileri çekilmiştir. Göç modeli için önce iki durumlu (birey göç etmiş/etmemiş) ardından çok durumlu logit model uygulanmıştır. Bireylerin son on yılda İstanbul’a göç etmesi bağıml değişkendir. İlden, ilçeden, köy-bucaktan İstanbul'a göç edip etmediği ile göç etmemiş bireylerden oluşan dört kategori mevcuttur. İstanbul'a göç etme olasıllğını veren iki durumlu logit modelden elde edilen sonuçlar ile "büyük kentler genç nüfusu çekmekte, daha yaşl nüfusu itmektedir" hipotezi desteklenmektedir. Bir diğer önemli bulgu, inşaat sektöründe çalışanların göç etme olasilı̆̆ıın daha fazla olduğudur. Ayrıca, bireylerin eğitim seviyesi arttıkça göreli olarak İstanbul’a göç olasılı̆̆ının pozitif yönde fakat giderek azaldı̆̆ı görülmektedir.

Anahtar kelimeler: İç göç, İstanbul, Logit model, Multinomial logit model.

\section{Giriş}

Tarih boyunca pek çok toplumun yaşadığı ve değişmez bir olgu olan göç, "insan gruplarının birlikte veya ayrı ayrı, sınırları belli bir yerleşim yerinden, diğer yerleşim yerlerine yönelik coğrafi ve sosyal hareketliliktir”. ${ }^{1}$ Ülkelerin demografik yapısını önemli şekilde etkileyen göç olgusu, neden ve sonuçları açısından hem birey hem de toplumları ekonomik, sosyal, kültürel ve psikolojik olarak etkilemektedir. Hiç şüphe

\footnotetext{
* Doç. Dr., Dokuz Eylül Üniversitesi, İktisadi ve İdari Bilimler Fakültesi, Ekonometri Bölümü.

** Prof. Dr., Dokuz Eylül Üniversitesi, İktisadi ve İdari Bilimler Fakültesi, Ekonometri Bölümü.

*** Prof. Dr., İzmir Katip Çelebi Üniversitesi, Sosyal ve Beşeri Bilimler Fakültesi, Psikoloji Bölümü.

1 Hüseyin Bal vd., "Göçle Gelenlerin Toplumsal Sorunları (Isparta Örneği)”, Süleyman Demirel Üniversitesi FenEdebiyat Fakültesi Sosyal Bilimler Dergisi, 27 (2012), s.192.
} 
yoktur ki, göç alan yerlerin yanı sıra göç veren yerler de süreçten önemli ölçüde etkilenmektedir. Dolayısıyla, çok ciddi dönüşümlere sebep olduğundan göç hareketlerinin bilimsel olarak incelenmesi ve araştırılması önem arz etmektedir. ${ }^{2}$

Sosyal bilimciler tarafından göç olgusuna yönelik farklı tür sınıflandırmalar yapılagelmiştir. Bu sınıflamalarda iradi olup olmama, süreklilik, amaç ve olayın gerçekleştiği yer rol oynamaktadır. İradi açıdan göçler "isteğe bağlı" ve "zoraki" olarak s1nıflandırılabilir. Ayrıca göçler, süreklilik açısından, özellikle de diğer yer değiştirme hareketlerinden farklı şekilde "devamlı göç" ya da "geçici göç" olarak da değerlendirilmektedir. Örneğin, mevsimlik tarım işçileri "geçici göç" kapsamında düşünülebilir. Yer değiştirmenin amacı yerleşmek olduğunda genellikle göçün gerçekleşmiş olduğu ifade edilmektedir. Yerleşme maksadı olmayan kısa süreli yer değiştirmeler ise, genellikle göç olarak değerlendirilmemektedir. ${ }^{3}$ Olayın gerçekleştiği yer bağlamında ise ulusal sınır dâhilinde olup olmama üzerinden bir açıklama yapılmaktadır. Bu bağlamda, iç veya dış göç şeklinde yapılan sınıflandırma kapsamında iç göç; bir ülke sınırları içinde, belli bir zaman diliminde yaşayan insan topluluklarının, kendi iradeleriyle, bölge, kent, kasaba ve köy gibi bir yerden bir diğerine yerleşmek amacıyla gerçekleştirdiği nüfus hareketi olarak değerlendirilebilir. ${ }^{4}$ Bir diğer boyutta yapılan sınıflamaya göre ise, iç ve dış göç ana ayrım noktası olup, bu temel göç tipleri kendi arasında alt boyutlara ayrılmaktadır. Buna göre, iç göç dörde ayrılarak, mevsimlik göç, sürekli-geçici göç, emek göçü, zorunlu-gönüllü göç şeklinde sinıflandırılabilmektedir. Diğer yandan diş göç ise, işçi göçü, beyin göçü, mübadele göçü, siyasal ve sosyo-ekonomik göçleri içermektedir. ${ }^{5}$

Genel olarak göç tiplerinin belirlenmesine ilişkin bir açıklama Peterson tarafından yapılmıştır. Buna göre, insanlar beş şekilde göç etmektedir. İlki, ilkel göçler olup, kötü hava koşulları, kuraklık gibi doğal çevre ve fiziki koşullardan kaynaklanan göçlerdir. İkincisi, zoraki göçler olup bu göç tipinde sosyal durumun yarattığı baskı vurgulanmaktadır. Üçüncüsü yine zoraki göçe benzer bir göç tipi olup burada yönlendirme söz konusudur. İkisi arasındaki fark, zoraki göçte göçmenlerin herhangi bir gücünün olmaması, yönlendirilen göçte ise göçmenlerin gücü bulunmakta ve karar mekanizmasını işletebilmektedirler. Dördüncü göç tipi serbest göç olup, topluluklar üzerinde herhangi bir baskı ya da zorlayıcı durum olmadan, göçmenlerin kendi bireysel tercih ve inisiyatifleriyle yaptığı göçten bahsedilmektedir. Kitlesel göç son göç tipidir. Kitlesel göçte, dünyadaki iletişim ve ulaşımın gelişmesiyle birlikte göçün kolektif bir olgu halinde gerçekleşmesinden bahsedilmektedir. ${ }^{6}$

2 Mustafa Öztürk ve Nihat Altuntepe, "Kentsel Alanlara Göç Edenlerin Kent ve Çalı̧̧a Hayatına Uyum Durumları: Bir Alan Araştırması", Journal of Yasar University, 11/3 (2008), s.1613.

3 Serpil Bülbül ve Ali Köse, "Türkiye’de Bölgelerarası İç Göç Hareketlerinin Çok Boyutlu Ölçekleme Yöntemi ile İncelenmesi", İstanbul Üniversitesi İșletme Fakültesi Dergisi, 39 (2010), s.77.

4 Ozan Bahar ve Fehime Korkmaz Bingöl, "Türkiye’de İç Göç Hareketlerinin İstihdam ve İşgücü Piyasalarına Etkileri", Süleyman Demirel Üniversitesi İktisadi ve İdari Bilimler Fakültesi Dergisi, 15/2 (2010), s.44; Bal vd., "Göçle Gelenlerin", s.192.

5 Enver Günay, Dilek Atılgan ve Emine Serin, "Dünya’da ve Türkiye’de Göç Yönetimi”, Kahramanmaraş Sütçü İmam Üniversitesi İktisadi ve İdari Bilimler Fakültesi Dergisi, 7/2 (2017), s.42.

6 William Peterson, "A General Typology of Migration", American Sociological Review, 23/3 (1958), s.259-263; Savaş Çağlayan, "Göç Kuramları, Göç ve Göçmen İlişkisi", Muğla Üniversitesi Sosyal ve Beşeri Bilimler Araştırmaları Dergisi, 17 (2011), s.75-76. 
Göçün nedenlerine ilişkin Farr, İngiltere ve Galler'de 1871 nüfus sayımı sonuçlara göre, göçün herhangi bir teori olmaksızın tesadüfen gerçekleştiğini öne sürmüştür. ${ }^{7}$ Ancak sonraları, insanların neden göç ettiklerine dair ortaya pek çok teori atılmıştır. Bunlardan kısaca bahsetmek gerekirse, göçün ekonomik olarak gelişmiş merkezlere doğru olmakta olduğunu iddia eden Ravenstein'ın "Göç Kanunları”8 adlı çalışmasına dayanarak, Lee tarafından ortaya atılan "itici” ve "çekici” güçlere ilişkin teoridir. Lee, göçlerin temel ortak özellikleri üzerinde durarak göçe ait itici ve çekici faktörleri saptamış ve dört temel faktör belirlemiştir: 1) Yaşanan yerle ilgili faktörler, 2) Gidilmesi düşünülen yerle ilgili faktörler, 3) İşe karışan engeller, 4) Bireysel faktörlerdir. ${ }^{9}$ Teori, kaynak bölgenin itici olmasına neden olan faktörler ile göç edilen yerin çekiciliğini sağlayan etkenler üzerinde durmaktadır. Kaynak yerin itici güçleri, tarım arazilerinin yetersizliği, işsizlik ve düşük gelir olabilirken; "çekici güçler" de yüksek gelir, istihdam firsatları, ekonomik durum, kentsel kamu hizmetleri olarak değerlendirilmektedir. ${ }^{10}$ Hemen her göç etme kararı bireyin yaşadığg yere ait itici faktörlerden ve hedef yerleşim yerinin çekici faktörlerinin karışımından etkilenmektedir. Göç eden bireyin, gideceği yere kıyasla halihazırda yaşadığı yer hakkında daha fazla bilgi sahibi olması itici faktörlerin birey tarafından daha iyi algılanmasına neden olacaktır. ${ }^{11}$ Ravenstein'in göçe ilişkin kanunları ile benzer şekilde Stouffer, sadece itme ve çekme kavramlarının yeterli olmayacağını, mesafe değişkeninin de göç etme kararı üzerinde etkili olduğunu ileri sürmüştür. Yazar aynı zamanda, göç edilen yer ile varış noktası arasındaki mesafenin kısa olmasının göçü olumlu etkileyen bir faktör olduğunu belirtmektedir. ${ }^{12}$ Ancak, arada engel olarak görülen mesafenin teknolojik gelişmeler, iletişim ve ulaşımın kolaylaşması ile birlikte sorun olmaktan çıktığı görülmektedir. Nispeten kolaylaşan ve maddi olarak erişilebilir hale gelen ulaşım imkânları ile birlikte, göç artış eğilimine girmektedir. Ulaşım, medya ve iletişimde yaşanan gelişmelerle birlikte hem göçün maliyeti düşmekte hem de bölgeler arasında yaşanan "psikolojik ve kültürel fark" da azalmakta ve bu durumdan göç olumlu etkilenmektedir. Tüm bu gelişmeler "iletici etkenler" olarak ele alınmaktadır. ${ }^{13}$

$\mathrm{Bu}$ çalışmanın konusu oluşturan ve bir ülkenin sınırları dâhilinde yapılan göçleri içeren iç göç olgusu Tekeli tarafından "belli bir zaman dilimi içinde belli bir yerleşme alanında yaşayanların, kendi iradeleriyle yaşam yerlerinin söz konusu yerleşme alanı dışına taşıyanların miktarı” şeklinde tanımlanmaktadır. Tekeli’nin tanımında da görüldüğü gibi, iç göçe ilişkin yapılan açıklamalarda dikkat çeken üç önemli unsur var-

7 Sibel Selim, “Türkiye’de Göç Kadınlaşıyor mu?: Ekonometrik Bir Analiz”, Adnan Menderes Üniversitesi Sosyal Bilimler Enstitüsü Dergisi, 4/3 (2017), s.43.

8 Ravenstein’n “Göç Kanunları” çalışmasında göçün mesafesi, kırsaldan kente yönelik göç, ticaret ve sanayi merkezlerine yönelik göç, kentlerde yaşayanlar ile kırda yaşayanların göç eğilimleri ve yine göç eğiliminde kadın erkek farkı gibi konulara odaklanan yedi kanun öne sürmektedir. Detaylı bilgi için bkz. Deniz Ela Özcan, “Çağdaş Göç Teorileri Üzerine Bir Değerlendirme”, İş ve Hayat Dergisi, $2 / 4$ (2017), s.188-189. Ayrıca bkz. Hakan Bostan "Türkiye’de İç Göçlerin Toplumsal Yapıda Neden Olduğu Değişimler, Meydana Getirdiği Sorunlar ve Çözüm Önerileri”, Coğrafya Dergisi, 35 (2017), s.5.

9 Aktaran Çağlayan, "Göç Kuramları", s.72.

10 Aktaran Fatih Çelik, "İç Göçlerin İtici ve Çekici Güçler Yaklaşımı ile Analizi”, Erciyes Üniversitesi İktisadi ve İdari Bilimler Fakültesi Dergisi, 27 (2006), s.150.

11 Bülbül ve Köse, “Türkiye’de Bölgelerarası İç Göç”, s.78.

12 Aktaran Özcan, “Çağdaş Göç Teorileri”, s.190-191.

13 Çelik, “İç Göçlerin”, s.156. 
dır. Bunların ilki “mekân”, ikincisi “zaman”, üçüncüsü de “irade” unsurudur. Mekân unsurunu, konut ve işyeri açısından değerlendirdiğimizde, bireyin birini veya her ikisini birden göç sürecinde değiştiriyor olması vurgulanmaktadır. Zaman unsuru ise, sosyal bilimciler açısından tartışmalı bir konu olmakla birlikte, alt sınır bir yıl olarak kabul edilmektedir. ${ }^{14}$ Örneğin kısa süreli, eğitim, çalışma amaçlı ve bu sürenin sonunda geri dönüş olan mekân değiştirmenin göç sayılıp sayılmayacağı tartışmalıdır. ${ }^{15}$ Son olarak, göç etme kararında birey ve/veya aile bireylerinin tercihini içinde barındıran irade durumu da göçü zorunlu göçten ayıran önemli bir unsurdur.

Bu çalışmanın amacı, Türkiye'nin nüfusu en yoğun kenti olan İstanbul'a yönelik iç göçte etkili olan demografik faktörleri belirleyip, kimin İstanbul'a göç ettiğini anlamaya yöneliktir. Daha açık bir ifadeyle, çalışmanın araştırma sorusu, İstanbul'a göç edenlerin, köy, ilçe ve kent düzeyinde, kim olduğunu, sosyo-demografik faktörler açısından ortaya çıkarmaktır. Çalışmada giriş bölümünü takiben; ikinci bölümde Türkiye'de ve İstanbul'a yönelik iç göçe ilişkin literatür taramasına yer verilmektedir. Sonraki araştırma bölümünde veri seti ve yöntem tanıtılmakta ve ayrıca ampirik bulgular yer almaktadır. Son bölümde ise bulgular değerlendirilip tartışılmakta, sonuç ve öneriler üzerinde durulmaktadır.

\section{Türkiye'de İç Göç Olgusu}

Ülkelerin büyüklük ve ekonomik kalkınmışlık düzeyine göre iç göçün, kırsaldan kente, kırsaldan kırsala, kentten kırsala doğru ve kentler arası gerçekleşmesi mümkündür. ${ }^{16}$ Türkiye'de göçler, yoğun olarak önceki dönemlerde kırdan kente yönelik iken, 1975 sonrası ve özellikle son yıllarda göçün akım yönünün kentten kente doğru olduğu görülmektedir. ${ }^{17}$ Günümüze değin kentler arası yaşanan bu göç örüntüsünde nüfus Doğu Anadolu kentlerinden Batı ve Güney Anadolu kentlerine doğru göç etmektedir. ${ }^{18}$ Türkiye'nin göç örüntüsünde, genel olarak sürekli göç veren ve göç alan bölgelerden söz edilebilmektedir. Başta Kuzeydoğu Anadolu Bölgesi olmak üzere Güneydoğu ve Karadeniz Bölgeleri sürekli göç vermekte iken İstanbul, Akdeniz, Marmara ve Batı Anadolu Bölgeleri ise göç alan bölgelerdir. ${ }^{19}$ Son yıllarda ise, kentten kırsala doğru da bir akım başladığı ve 1995-2000 döneminde, bu oranın kırdan kente olan göç oranından fazla olduğu bile görülmektedir. ${ }^{20}$ Halen bölgelerin refah düzeyi, eğitim ve kentleşme düzeyi, Türkiye’de yaşanan iç göçü olumlu etkilerken, tüm bu alanlardaki gelişmişlik düzeyi kentlerin çekiciliğini artırırken, başta ekono-

14 Aktaran Mustafa Şen, “Türkiye’de İç Göçlerin Neden ve Sonuç Kapsamında İncelenmesi”, Çalışma ve Toplum, 1 (2014), s.233; Bülbül ve Köse, “Türkiye’de Bölgelerarası İç Göç”, s.78.

15 Serdar Sağlam, “Türkiye’de İç Göç Olgusu ve Kentleşme”, Türkiyat Araştırmaları, Erman Altun Özel Kitaplı̆̆l, 5 (2006), s.34.

16 Ertuğrul Güreşçi, “Ortak ve Farklı Yönleriyle İç ve Dış Göçler”, Journal of International Social Research, 9/43 (2016), s.1059.

17 Kentleşme Şurası, Kentsel Yoksulluk, Göç ve Sosyal Politikalar. Ankara: T.C. Bayındırlık ve İskân Bakanlığı, 2009, s.17; İçduygu, Türkiye’de İç Göç, s.216.

18 Ferhunde Özbay ve Banu Yücel, Türkiye'de Göç Hareketleri, Devlet Politikaları ve Demografik Yapı, Nüfus ve Kalkınma: Göç, Eğitim, Demokrasi, Yaşam Kalitesi, haz., Ferhunde Özbay vd. Ankara: Hacettepe Üniversitesi Nüfus Etütleri Enstitüsü Yayınları, 2001, s.34.

19 Bülbül ve Köse, “Türkiye’de Bölgelerarası İç Göç”, s.91.

20 Kaştan, “Türkiye'de Cumhuriyet Dönemi”, s.696. 
mik sorunlar ve terör olgusu yapılacak göç için itici bir faktör halindedir. ${ }^{21}$

İç göçlerin önemli bir nedeni refah ve ekonomik gelişmenin tüm bölgelere eşit dağılmamış olmasıdır. Türkiye'de iç göçün durumunu "1950 öncesi göçler”, "1950-1985 arası göçler” ve “1985 sonrası göçler” şeklinde üçe ayıran Akşit, 1950’lere değin köyün modernizasyonu bağlamında, çalıştırılmak üzere geniş kitlelerin topraktan koparılıp işçi haline dönüştürülmesi üzerinde durmaktadır. 1950 ila 1985 yılları arasında Türkiye nüfusu kırsaldan kente göç ederek önemli bir değişim göstermektedir. ${ }^{22}$ 1950'den itibaren kentin sanayileşme hamlesi ile artan işgücü ihtiyacı kırsalda işsiz kalan insanların kentlere doğru göç etmesine neden olmuştur. ${ }^{23}$ Bu dönemde tarımda yaşanan dönüşüm kırsalda itici bir faktör olarak algılanmış, sanayileşme ile birlikte çekici hale gelen kentler yaşanan iç göç ile birlikte önemli nüfus artışlarına sahne olmuştur. 1950'lerde nüfusun neredeyse dörtte biri kentlerde yaşarken, 1960’lara gelindiğinde kentli nüfus oranı \% 30 civarına yükselmiştir. ${ }^{24} \mathrm{Bu}$ göç döneminde, sırasıyla önce İstanbul, Ankara ve İzmir gibi kentlerin yakın çevresindeki kırsal alanlardan bu kentlere yönelik yoğun göç yaşanmıştır. Sonrasında, Orta Anadolu ve Karadeniz kırsalından büyük kentlere doğru göç hareketliliği görülmüş ve en son olarak Doğu ve Güneydoğu Anadolu kırsalından büyük kentlere doğru göçün artış gösterdiği görülmüştür. 1980’lerde Türkiye nüfusunun çoğunluğu kentlerde yaşamaya başlamıştır. Ancak, Türkiye’nin göç örüntüsü sadece kırdan kente yönelik değildir. 1965-1985 yılları arasındaki göçü inceleyen bir çalışmada, il merkezinden il merkezine, köyden il merkezine, il merkezinden ilçe merkezine, ilçe merkezinden ilçe merkezine, köyden ilçe merkezine, il merkezinden köye, ilçe merkezinden köye ve köyden köye gibi dokuz farklı tipte iç göç örüntüsü olduğu sonucu elde edilmiştir. ${ }^{25}$ Elbette bu göç örüntüleri dönemlere göre farklılık göstermektedir. Örneğin 1960’ların kırdan kente göç örüntüsü 1970'lerin sonundan itibaren yerini kentten kente göçe bırakmıştır. ${ }^{26}$ Ayrıca, ilk dönemlerde, Türkiye’de göçlerin daha çok üretim ilişkisinden etkilendiği görülmekte ve bu sebeple, göç edenlerin itici faktörlere bağlı olarak kırdan kente doğru yönelmekte olduğu gözlenmektedir. Kırsalda özellikle gençlerin düşük gelire sahip olması, bölgenin sosyal ve ekonomik açıdan az gelişmiş olması kırsalın itici özellikleri olarak belirtilebilir. Kentler açısından ise, yeni sanayileşme hamlelerinin başlaması, istihdam olanaklarının bu bölgede olması kentlerin çekiciliğini arttırarak kırdan kente doğru göç hareketlerinin yaşanmasına neden olmuştur. Diğer taraftan, sermaye sahiplerinin de kentten kente göç etmekte olduğu görülmektedir. ${ }^{27}$

\footnotetext{
21 Dilek Özdemir, “Türkiye’de Bölgelerarası İç Göç Hareketlerinin Belirleyicileri”, Atatürk Üniversitesi Sosyal Bilimler Enstitüsü Dergisi, 22/3, (2018), s.1348.

22 Bahattin Akşit, İçgöçlerin Nesnel ve Öznel Toplumsal Tarihi Üzerine Gözlemler: Köy Tarafından Bir Bakış, Türkiye'de İç Göç. haz., Ahmet İçduygu, İstanbul: Türkiye Ekonomik ve Toplumsal Tarih Vakfı, 1998, s.2-9.

23 Gaye Karpat-Çatalbaş ve Ömer Yarar, “Türkiye’deki Bölgeler Arası İç Göçü Etkileyen Faktörlerin Panel Veri Analizi ile Belirlenmesi”, Alphanumeric Journal, 3/1 (2015), s.100.

24 Savaş Çağlayan ve Asiye Kemik, "Kırdan Kente İç Göç Süreciyle Kadınların İş Yaşamına Katılımları ve Sonuçları”, Süleyman Demirel Üniversitesi Fen-Edebiyat Fakültesi Sosyal Bilimler Dergisi, 43 (2018), s.146.

25 Ayşe Gedik, "Internal Migration in Turkey, 1965-1985: Test of Conflicting Findings in The Literature”, Review of Urban \& Regional Development Studies, 9/2 (1997), s.170.

26 Öztürk ve Altuntepe, “Kentsel Alanlara Göç”, s.1598.

27 Yüksel Kaștan, “Türkiye’de Cumhuriyet Dönemi İç Göç Hareketleri”, Journal of International Social Research. 9/42, (2016), s.697.
} 
Türkiye'deki iç göç hareketinin gelişmiş ülkelerden ayrılan en önemli özelliği, ülkede hızlı kentleşmenin sanayileşme ile paralel bir hızda gerçekleşmemesidir. Daha açık bir ifadeyle, gelişmiş ülkelerdeki sanayileşmeye bağlı kentleşme Türkiye'de yaşanmamıştır. Çünkü sanayi sektörünün büyüme hızı iç göç hızını karşılayamamıştır. $^{28}$ Dolayısıyla, Türkiye'de kontrolsüz büyüyen kentleşme, sanayileşmenin yeterli düzeyde gelişiminden daha önce bir sorun haline gelmiştir. Bu durumun kaçınılmaz bir sonucu olarak, kentlere iç göçle gelmiş olanlar kayıtlı sektörde iş bulamadıkları için kayıt dışı çalışmak zorunda kalmış ve sendikalı ya da kayıtlı işgücü ile ucuz emek ekseninde bir rekabete girmiştir. ${ }^{29}$ Ylllarca süren sanayileşme çabalarına rağmen, Türkiyede sanayi, iş arayanların sadece belli bir bölümüne iş imkânı sunulabilmektedir. Özel ve kamu işletmelerindeki istihdam olanakları da sınırlı olduğundan, büyük şehirlerdeki kayıt dışı sektörler kırdan kente göç etmiş çok sayıda kişi için kent ekonomisine katılımın temel yolu olmuştur. ${ }^{30} \mathrm{Bu}$ göçmenlerin bazıları akraba, hemşeri ve iş arkadaşlarının yardımlarıly kayıtlı sektörde iş bulabilmektedir. Örneğin, İstanbul'a göçle gelmiş 274 semt pazarcısı üzerinde yapılan bir anket çalışmasının bulgularına göre, katılımcıların \% 51'i geleneksel aile, akraba ve hemşeri dayanışması sayesinde hemen iş bulabildiklerinin ifade etmiştir. ${ }^{31}$ Söz konusu geleneksel bağlar nedeniyle de Türkiyede belli bir yerden yine belli bir yere göç zincirlerinin oldukça yaygın olduğu anlaşılmaktadır. ${ }^{32}$ Kırdan kente göç eden, kayıtlı sektörde iş bulamayan göçmenler düşük ücretli, düzensiz, istikrarsız ve güvencesiz şekilde de olsa, kendilerine bir olanak sağlayan ve derin yoksulluk içine düşmelerini bir ölçüde engelleyen, kayıt dışı sektörde yer edinebilmektedir. Daha önce de belirtildiği gibi, bu sürdürülebilirlikten uzak olan duruma, kırdan kente göçün yoğun olması, göç edenlerin vasıf ve eğitim düzeyinin düşük olması ve kentin gerektirdiği vasıf düzeyini karşılayamaması, kayıtlı sektördeki istihdama ilişkin fırsatlarının yetersizliği gibi faktörler neden olmaktadır. ${ }^{33}$

\section{İstanbul'a Yönelik İç Göç}

Türkiye nüfusunun önemli bir kısmını barındırması, ülkenin ekonomik, sosyal ve kültürel açıdan en canlı kent olması sebebiyle İstanbul, pek çok disiplin tarafından araştırma konusu olmuştur. İstanbul’a yönelik iç göç hareketleri üzerinde durmak gerekirse, İstanbul 1950'lerden itibaren yoğun bir iç göçle karşı karşıyadır. ${ }^{34}$ Özellikle 1980 sonrası dönemde, göç destinasyonu olarak İstanbul'u konu edinen araştırma-

28 Ned Levine ve Sunday Üner, Population Policy Formation and Implementation in Turkey, Ankara: Hacettepe Nüfus Etüdleri Enstitüsü Yayını, 1978, s.16.

29 Ahmet İçduygu, İbrahim Sirkeci ve İsmail Aydıngün, Türkiye'de İç Göç ve İç Göçün İşçi Hareketine Etkisi, Türkiye’de İç Göç, haz., Ahmet İçduygu, İstanbul: Türkiye Ekonomik ve Toplumsal Tarih Vakfı, 1998, s.225. 30 Işık Urla Zeytinoğlu vd., "Migrant Women in Waged Domestic Work in Turkey”, Middle East Report, 29/2 (1999), s.43.

31 Öztürk ve Altuntepe, "Kentsel Alanlara Göç”, s.1598.

32 Mohammad Hemmasive Carolyn V. Prorok, “Women's Migration and Quality of Life in Turkey”, Geoforum, 33 (2002), s.401.

33 Nadir Suğur vd., "Hizmet Sektöründe Çalışan Yoksulların Geçim Stratejileri ve Sosyal İlişki Ağları: Eskişehir Örneği”, İş, Güç Endüstri İlişkileri ve İnsan Kaynakları Dergisi, 12/1 (2000), s.64; Öztürk ve Altuntepe, "Kentsel Alanlara Göç", s.1618.

34 Ali Gürel ve Yasemin Balta, “İstanbul’un Göç Olayı ve Etnik Hayat Üzerine”, Marmara Sosyal Araştırmalar Dergisi, 1 (2011), s.4. 
larda büyük artış yaşanmıştır. İzmir-Van hatıının kuzeyinde, genellikle de Karadeniz ve Marmara bölgesi halkı için İstanbul, birinci derecede tercih edilen bir kenttir. ${ }^{35}$ Bu durum, giriş kısmında açıklandığı gibi, coğrafi yakınlığın göç üzerindeki etkisini göstermektedir. Türkiye'de en fazla göç alan kentlerin başında gelen İstanbul, pek çok açıdan, diğer illere göre daha fazla çekici özelliklere sahiptir.

Trabzon'dan İstanbul'a göç etmiş olan 500 katılımcı üzerinde anket yoluyla gerçekleştirilen bir araştırmada, katılımcılar göç etme nedenlerini ilk sırada "çalışmak, iş bulmak", ikinci sırada da "daha çok para kazanmak, iş imkânlarının çokluğu” olarak belirtmişlerdir. Üçüncü sırada ise, ekonomik nedenlerden farklı olarak, katılımcılar "sosyal hayatın çekiciliği, şehir hayatının güzelliği” nedeniyle İstanbul'a göç ettiklerini ifade etmişlerdir. ${ }^{36} \mathrm{Bu}$ araştırmanın bulguları, İstanbul'un hem ekonomik hem de sosyal açıdan gelişmişliği nedeniyle göç için çekici bir kent konumunda olduğunu göstermektedir.

İstanbul'a Ağrı, Kars, Iğdır, Ardahan illerini içine alan TRA2 Bölgesinden göç etmiş 1944 katılımcıyla gerçekleştirilen bir diğer anket çalışmasının göç nedenlerine ilişkin bulgusuna göre, İstanbul'a göçte ekonomik nedenler ilk sırada yer almaktadır. İkinci sırada eğitim, üçüncü sırada akrabaların İstanbul’a göç etmiş olması, dördüncü sosyal yaşamin yetersizliği ve son olarak göç edenlerden gelen olumlu bilgiler göç kararında önemli etkenler olarak görülmüştür. ${ }^{37}$ Kırdan kente yönelik göçte, kadınların İstanbul'u neden tercih ettiklerine ilişkin yapılan bir başka çalışmada; kentin sahilde konumlanması, kentin refahı, kentteki barınma imkânı çekici faktörler, itici faktör olarak da kırsalın yoksunluğunun açıklayıcı olduğu görülmüştür. Çalışmada, İstanbul'un göç destinasyonu olarak tercih edilmesinin nedenleri olarak, İstanbul'un tarihi altyapısı, sosyal, ekonomik ve kültürel dinamizminin yanı sıra kentin kıyı şeridindeki konumu vurgulanmaktadır. Göç sonrası iş firsatları açısından da avantajlı olan İstanbul'da, kadınların tekstil atölyelerinde çalışmaktan evde elektronik parçaların birleştirilmesine kadar geniş yelpazedeki iş olanaklarından bahsedilmektedir. ${ }^{38}$

Bu çalışmada İstanbul'a göç edenlerin; köy, ilçe ve kent düzeyinde, kim olduğunu, sosyo-demografik ve ekonomik faktörler açısından ortaya çıkararak özellikle kişinin çalıştığı sektör de dikkate alındığından ilgili yazına ilave bir katkısı olacağı düşünülmektedir. Özellikle İstanbul'a yönelik göçü konu edinen bu çalışmanın, İstanbul'un göç alan iller arasındaki konumunun değiştiği bir zamana denk gelmesi önemlidir. Aslında 2018 yılı Adrese Dayalı Nüfus Kayıt Sistemi sonuçlarına göre, İstanbul'un nüfusu 15 milyon 67 bin 724 kişiye ulaşmıştır. Bu haliyle İstanbul, aşağıda Tablo 1'den de görülebileceği gibi, nüfusu devamlı olarak artış eğiliminde olan, Türkiye nüfusunun \%18,4'ünün ikamet ettiği en kalabalık il ${ }^{39}$ olsa da geçmişten gelen yoğun

35 Alaettin Tandoğan, "Türkiye Nüfus Hareketlerinde İstanbul'un Yeri”, Coğrafya Araștırmaları, 1/1 (1989), s.137; Gürel, "İstanbul'un Göç Olayı", s.4.

36 Mustafa Şen, "Trabzon'dan İstanbul’a Göç Edenlerin Sosyo-Ekonomik Analizi”, Çalışma Dünyası Dergisi, 2/3 (2014), s.50.

37 Hüseyin Tutar ve Deniz Özyakışır, “TRA2 Bölgesinden İstanbul’a Göç Hareketlerinin Nedenlerine İlişkin Bir Araştırma”, Sosyoloji Konferanslart, 47/1 (2013), s.53.

38 Hemmasi, "Women's Migration", s.409.

39 ADNKS, 2018. 
iç göç dalgası 2017-2018 döneminde değişim göstermiştir. Bu dönemde, aldığı göçün 385 bin 482, verdiği göçün de 595 bin 803 olması ile birlikte, İstanbul'da net göç hızının -13,9 ile ciddi bir düşme eğilimi içinde olduğu görülmektedir. İstanbul'un net göç hızı ilk olarak -4,8 ile 2015-2016 döneminde düşüş eğilimine girmiştir. Çalışma bu döneme ait veriler üzerinden analiz yaptığı için de ayrıca önem taşımaktadır.

Tablo 1. İstanbulun Nüfusu (1960-2015)

\begin{tabular}{|l|l|l|l|}
\hline Yll & Nüfus & Yil & Nüfus \\
\hline 1960 & 1.882 .092 & 2000 & 10.018 .735 \\
\hline 1965 & 2.293 .823 & 2007 & 12.573 .836 \\
\hline 1970 & 3.019 .032 & 2010 & 13.255 .685 \\
\hline 1975 & 3.904 .588 & 2015 & 14.657 .434 \\
\hline 1980 & 4.741 .890 & 2016 & 14.804 .116 \\
\hline 1985 & 5.842 .985 & 2017 & 15.029 .231 \\
1990 & 7.309 .190 & 2018 & 15.067 .724 \\
1997 & 9.198 .809 & & \\
\hline
\end{tabular}

Kaynak: 1960-2000 yılları arası Genel Nüfus Sayımı ve 2007-2015 yılları arası Adrese Dayalı Nüfus Kayıt Sistemi verileri ile hazırlanmıştır.

\section{Veri Seti ve Yöntem}

$\mathrm{Bu}$ araştırmanın veri seti 15 ve daha yukarı yaştaki fertlere sorulan işgücü bilgilerinden oluşmaktadır. Türkiye İşgücü Araştırması 2015 ham verilerinden yararlanarak İstatistiki Bölge Birimleri Sınıflamasından (İBBS 2. Düzey) İstanbul verileri çekilmiştir. "Doğduğunuzdan beri sürekli olarak bu ilde mi yaşıyorsunuz?", "Hangi yıldan itibaren bu ilde yaşıyorsunuz?", "Bu ilden önce ikamet ettiğiniz yer Türkiye mi, yoksa yurt dışı mı?" ve "Daha önce ikamet ettiğiniz bu yerleşim yeri sayacaklarımdan hangisidir?” sorularına verilen cevaplardan bir veri seti oluşturulmuştur. Bunlar Türkiyede yaşayan, en fazla on yıldır İstanbul'da ikamet eden ve daha önce sırasıyla ilden, ilçeden, köy ve bucaktan İstanbul'a göç eden bireylerdir. Referans kategori İstanbul'da oturanlardır. Bağımsız değişkenler ise cinsiyet, yaş, eğitim düzeyi, hane halkı büyüklügüu, işgücü kapsamında bulunan kişinin işgücü kapsamında bağlı bulunduğu sektördür. Ayrıca Avrupa Topluluğunda Ekonomik Faaliyetlerin İstatistiki Sınıflamasından (NACE Rev 2) yararlanarak işgücündeki bireyin sektör kodları tarım, maden-imalat, inşaat, hizmet şeklinde oluşturulmuştur. İstanbul'da tarım sektöründe çalışan sadece otuz kişi olduğundan bunlar veri setinden çıarılmıştır. İşsiz ve işgücüne dahil olmayanlarda bir değişken olarak eklenmiştir.

Nominal tercihlerde en çok kullanılan model çok durumlu logit model iken IIA varsayımının sağlanmaması durumunda çok durumlu probit model tercih edilmektedir. Bu nedenle elde edilen çok durumlu logit model sonuçlarına göre IIA varsayımı test edilmiştir.

\section{Teorik Çerçeve}

Sıralı olmayan tercihler için en çok kullanılan modellerden biri olan çok durumlu 
logit model, tesadüfi fayda modeline dayanmaktadır. J adet tercihi ele almak amacryla tasarlanan çok durumlu logit modelde $J \geq 3$ olmak üzere m. tercihin i. birey tarafından seçilme olasılığı Denklem (1)'de gösterilmiştir ${ }^{40}$ :

$$
P\left(Y_{i}=m \mid x_{i}\right)=\frac{\exp \left(x_{i} \beta_{m}\right)}{1+\sum_{j=2}^{J} \exp \left(x_{i} \beta_{j}\right)} \quad m>1 \quad \beta_{1}=0
$$

Burada $Y_{i}$, ínci birey için bağımlı değişken vektörü iken $x_{i}$ bağımsız değişken vektörüdür ve aynı zamanda bireyin tercihlere göre değişmeyen karakteristiklerini temsil etmektedir. $\bigotimes_{j}$, j alternatifinin seçilme olasılığına bağımsız değişken vektörünün katkısını, $\bigotimes_{m}$ ise $\mathrm{m}$ alternatifinin tercihinde bağımsız değişken vektörünün katkısını ölçmektedir. Tahminlenen eşitlikler, $x_{i}$ karakteristikleri ile bir karar verici için J adet seçimin olasılık setinin elde edilmesini sağlamaktadır. Çok durumlu logit modelin tahminlenmesinde en yüksek olabilirlik yöntemi kullanılmaktadır.

Çok durumlu logit model'in en önemli kısıtı İlişkisiz Alternatiflerin Bağımsızlı̆̆ı (IIA) varsayımıdır. Bunun nedeni hata terimlerinin hem bağımsız olması hem de gumbell dağılımına sahip olmalarının belirlenmesinin güçlügünden kaynaklanmaktadır. IIA varsayımı; herhangi iki alternatifin tercih edilme olasılıklarının birbirine oranının, tercih kümesinde başka alternatifler bulunup bulunmamasından bağımsız olduğunu ifade eder. Bu nedenle IIA varsayımının sağlanıp sağlanmadığı istatistiksel olarak test edilmesi gerekmektedir. Hausman ve McFadden tarafından önerilen Hausman-tipi IIA test istatistiği ile yapılan bu test için temel hipotez, modelde yer alan iki tercih alternatifinin oluşturduğu fark oranının, diğer bir tercih alternatifinin varlığından veya yokluğundan bağımsız olduğudur. Başka bir deyişle i IIA varsayımı geçerlidir şeklindedir ve test istatistiği aşağıdaki Denklem (2)'de gösterilmiştir:

$$
\chi^{2}=\left(\hat{\beta}_{s}-\hat{\beta}_{f}\right)^{\prime}\left[\hat{V}_{s}-\hat{V}_{f}\right]^{-1}\left(\hat{\beta}_{s}-\hat{\beta}_{f}\right)
$$

$k$ serbestlik dereceli sınırlı $\chi^{2}$ dağılımı gösteren bu istatistiğe göre $s$; sınırlandırılmış kümeye dayalı tahminleri, $f$ de tüm tercihler kümesine dayalı tahminleri temsil etmektedir. $^{41}$

IIA varsayımının test edilmesinde kullanılan bir diğer test Small ve Hsiao IIA testidir. Small-Hsiao testini gerçekleştirmek için örneklem iki eşit alt örnekleme ayr1lır. Sınırlandırılmamış çok durumlu logit model her bir alt örneklem için aşağıdaki denklem (3) ile tahmin edilmektedir:

40 Russell Davidson ve James Gordon Mac Kinnon, Econometric Theory and Methods, New York: Oxford University Press, 1999, s.460.

41 Daniel McFadden, "Econometric Analysis of Qualitative Response Models”, Handbook of Econometrics, haz., Zvi Griliches ve Michael Intriligator, Amsterdam: Elsevier Science B.V., 1984, s.1417-1418. 


$$
\hat{\beta}_{u}^{S_{1} S_{2}}=\left(\frac{1}{\sqrt{2}}\right) \hat{\beta}_{u}^{S_{1}}+\left[1-\left(\frac{1}{\sqrt{2}}\right)\right] \hat{\beta}_{u}^{S_{2}}
$$

Burada $\hat{\beta}_{u}^{S_{1}}$, birinci alt örnekleme uygulanan sınırlandırılmamış çok durumlu logit model ile elde edilen tahminleri; $\hat{\beta}_{u}^{S_{2}}$ ise ikinci alt örneklemden elde edilen tahminleri göstermektedir. Daha sonra ikinci alt örneklem kullanılarak bağımlı değişkenin seçilen bir değeri ile sınırlandırılmış örneklem oluşturulur. Bu sınırlandırılmış örneklem ile çok durumlu logit model tahmin edilip $\hat{\beta}_{r}^{S_{2}}$ tahminleri elde edilir. K bağımsız değişken sayısı olmak üzere $(\mathrm{K}+1)$ serbestlik dereceli $\chi^{2}$ dağılımı gösteren Small-Hsiao istatistiği Denklem (4)'te gösterilmiştir. ${ }^{42}$

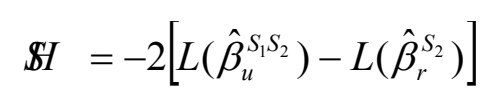

\section{Ampirik Bulgular}

Göç modeli için önce iki durumlu (birey göç etmiş/etmemiş); takiben çok durumlu logit model uygulanacaktır.

Tablo 2'ye göre iki durumlu logit modelde kullanılan bağımlı değişken iki kategoriden oluşmakta ve "ilden İstanbul'a göç etmiş" ait birey sayısı 4414 kişi iken diğer kategori olan İstanbul'da ikamet eden, başka bir deyişle göç etmeyen birey sayısı 11683 kişidir.

Çok durumlu logit modelde kullanılan bağımlı değişken ise dört kategoriden oluşmaktadır ve Tablo l'de görüldügü üzere "ilden İstanbul’a göç etmiş" birey sayısı 1176 iken, ilçeden göç edenlerin sayısı 1655, köy ve bucaktan göç edenlerin sayısı 1583 kişidir. Bu modelde de yine aynı şekilde göç etmeyen birey sayısı 11683 kişidir. Burada özellikle "ilçeden İstanbul'a göç etmiş" birey sayısının ilden göç edenler ile köy ve bucaktan göç edenlerden daha fazla olduğu görülmektedir.

Tablo 2. Bireylerin Göç Dağılımı

\begin{tabular}{|l|c|c|}
\hline Göç Durumu & $\begin{array}{c}\text { İki durumlu logit } \\
\text { modelde kullanılan } \\
\text { bağımlı değişken }\end{array}$ & $\begin{array}{c}\text { Çok durumlu logit } \\
\text { modelde kullanılan } \\
\text { bağımlı değişken }\end{array}$ \\
\cline { 1 - 1 } İlden İstanbul'a göç etmiş & 4414 & 1176 \\
\hline İlçeden İstanbul'a göç etmiş & & 1655 \\
\cline { 1 - 1 } Köy ve bucaktan İstanbul'a göç etmiş & & 1583 \\
\hline $\begin{array}{l}\text { İstanbul'da ikamet ediyor (göç } \\
\text { etmemiş) }\end{array}$ & 11683 & 11683 \\
\hline Toplam & 16097 & 16097 \\
\hline
\end{tabular}

42 J. Scott Long ve Jeremy Freese, Regression Models for Categorical Dependent Variables Using Stata, USA: Stata Press, 2001, s.189. 
Tablo 3'te ise çalışmada kullanılan açıklayıcı değişkenlere ilişkin tanımlayıcı istatistikler yer almaktadır.

Tablo 3. Tanımlayıcı Ístatistikler

\begin{tabular}{|c|c|c|c|}
\hline Değişken & & Ortalama & $\begin{array}{c}\text { Standart } \\
\text { Sapma }\end{array}$ \\
\hline $\begin{array}{l}\text { Hane halkı } \\
\text { büyüklüğ̈ü }\end{array}$ & & 3.9763 & 1.6589 \\
\hline \multirow[t]{2}{*}{ Cinsiyet } & Erkek & 0.4851 & 0.4997 \\
\hline & Kadın & 0.5149 & 0.4997 \\
\hline \multirow[t]{11}{*}{ Yaş Durumu } & 15-19 Yaş & 0.1969 & 0.3976 \\
\hline & 20-24 Yaş & 0.1675 & 0.3734 \\
\hline & 25-29 Yaş & 0.0325 & 0.1774 \\
\hline & 30-34 Yaş & 0.1572 & 0.3640 \\
\hline & 35-39 Yaş & 0.1369 & 0.3438 \\
\hline & 40-44 Yaş & 0.0968 & 0.2957 \\
\hline & 45-49 Yaş & 0.0782 & 0.2685 \\
\hline & 50-54 Yaş & 0.0492 & 0.2162 \\
\hline & 55-59 Yaş & 0.0369 & 0.1886 \\
\hline & 60-64 Yaş & 0.0301 & 0.1711 \\
\hline & 65 Yaş ve üstü & 0.0172 & 0.1302 \\
\hline \multirow[t]{6}{*}{ Eğitim Durumu } & Okul bitirmedi & 0.0583 & 0.2343 \\
\hline & İlkokul mezunu & 0.1836 & 0.3872 \\
\hline & Ortaokul mezunu & 0.2875 & 0.4526 \\
\hline & Lise mezunu & 0.2558 & 0.4363 \\
\hline & Yüksekokul/Fakülte mezunu & 0.1943 & 0.3957 \\
\hline & Yüksek Lisans/Doktora mezunu & 0.0201 & 0.1406 \\
\hline \multirow[t]{4}{*}{ Medeni Durum } & Evli & 0.4678 & 0.4989 \\
\hline & Boşand1 & 0.0332 & 0.1794 \\
\hline & Eşi öldü & 0.0226 & 0.1486 \\
\hline & Bekar & 0.4762 & 0.4994 \\
\hline \multirow[t]{4}{*}{ Sektör } & İnşaat & 0.0305 & 0.1719 \\
\hline & Hizmet & 0.3269 & 0.4691 \\
\hline & Madencilik/İmalat & 0.1202 & 0.3252 \\
\hline & İşi Yok/Çalışmıyor & 0.5223 & 0.4995 \\
\hline
\end{tabular}

Tablo 3'teki tanımlayıcı istatistiklere göre ortalama hane halkı büyüklüğü 3.97 iken, anketi cevaplayan kişilerin yaklaşık \% 49’u erkek, \% 51'i ise kadındır. Çalışmada yaş grubuna bakıldığında \%19.69 ile en fazla 15-19 yaş arasında kişilerin olduğu görülmekte, ardından \% 15.72 ile ise 30-34 yaş arasındaki kişiler gelmektedir. En az \% 1.72 ile 65 yaş ve üstü bireyler bulunmaktadır. Eğitim durumunda ise \% 28.75 ile en fazla ortaokul mezunu olan bireylerin olduğu görülmektedir. Bunu \% 25.58 ile lise mezunu bireyler takip etmektedir. Araştırma konusu olan bireylerin \% 47.62'si bekâr iken, \% 46.78'i evli ve \% 3'ü boşanmış, \% 2'sinin ise eşi ölmüştür. Son olarak kişilerin sektör grubuna bakıldığında \% 32.69 ile en fazla hizmet sektöründe, \% 12.02 ile madencilik/imalat sektöründe ve \% 3 ile inşaat sektöründe oldukları anlaşılmaktadır. 
Çok durumlu logit modelde IIA varsayımının sağlanmaması durumunda çok durumlu probit model tercih edilmektedir. Bu nedenle tahmin edilen model sonuçlarına göre IIA varsayımı test edilmiştir.

Tablo 4. IIA Varsayımı için Hausman Testi

\begin{tabular}{|l|l|l|l|l|}
\hline Modelden Dişlanan Alternatif & chi2 & s.d. & P>chi2 & Karar \\
\hline İlden göç edenler & 45.098 & 48 & 0.592 & $\mathrm{H}_{0}$ reddedilemez \\
\hline İlçeden göç edenler & 44.242 & 48 & 0.628 & $\mathrm{H}_{0}$ reddedilemez \\
\hline Bucak ve köyden göç edenler & -419.437 & 48 & --- & --- \\
\hline
\end{tabular}

Not: s.d., serbestlik derecesini göstermektedir.

Hausman test sonuçları Tablo 4'te verilmiştir. Hausman testine göre sıfır hipotezi alternatiflerin birbirinden bağımsız olduğunu söylemektedir. Temel sınıf "bireyin göç etmediği” alternatifine göre "ilden göç edenler” ve "ilçeden göç edenler” kategorileri için önem düzeylerine bakıldığında $\% 5$ 'ten büyük olduğu görülmekte ve $\mathrm{H}_{0}$ hipotezi kabul edilmektedir. Fakat "bucak ve köyden göç edenler"deki kare değeri negatif çıkmıştır. Bu durumda tahminlenen model Hausman testinin asimptotik varsayımlarını karşılamadığı için bir karar verilememiştir. IIA varsayımının sağlanması konusunda alternatif bir test olan Small-Hsiao testi aşağıdaki Tablo 5 'te kullanılmıştır. ${ }^{43}$

Tablo 5. IIA Varsayımı için Small-Hsiao Testi

\begin{tabular}{|l|l|l|l|l|l|l|}
\hline $\begin{array}{l}\text { Modelden Dışlanan } \\
\text { Alternatif }\end{array}$ & $\operatorname{lnL}($ full) & $\operatorname{lnL}$ (omit) & chi2 & s.d. & P>chi2 & Karar \\
\hline İlden göç edenler & -4207.453 & -4179.209 & 56.487 & 48 & 0.188 & $\mathrm{H}_{0}$ reddedilemez \\
\hline İlçeden göç edenler & -3610.754 & -3582.623 & 56.261 & 48 & 0.193 & $\mathrm{H}_{0}$ reddedilemez \\
\hline $\begin{array}{l}\text { Bucak ve köyden göç } \\
\text { edenler }\end{array}$ & -4166.666 & -4142.796 & 47.741 & 48 & 0.483 & $\mathrm{H}_{0}$ reddedilemez \\
\hline
\end{tabular}

Not: s.d., serbestlik derecesini göstermektedir.

İlden göç edenler, ilçeden göç edenler ile bucak ve köyden göç edenler için önem düzeylerine bakıldığında, bütün kategorilerde önem düzeyi değerleri \%5'den büyüktür, böylece $\mathrm{H}_{0}$ hipotezi reddedilemez. Hausman testine göre IIA varsayımı sağlanamazken, Tablo 5'te görülen Small ve Hsiao testine göre IIA varsayımı sağlanmıştır. Alternatiflerin birbirinden bağımsız olduğu söylenebilir. Model, çok durumlu logit tahminine uygundur. Öncelikle iki durumlu logit model üzerinde durulacaktır.

Tablo 6. İki Durumlu Logit Model

\begin{tabular}{|l|l|l|}
\hline Bă̆ımlı Değişken & Göç Etme Durumu & \\
\hline Değişken & & Katsayı \\
\hline Sabit Terim & & $-3.394^{* * *}$ \\
\hline Hane halkı büyüklüğ̈ü & & $0.112^{* * *}$ \\
\hline \multirow{2}{*}{ Cinsiyet } & Erkek & $0.073^{*}$ \\
\cline { 2 - 3 } & Kadın & T.S. \\
\hline
\end{tabular}




\begin{tabular}{|c|c|c|}
\hline \multirow[t]{11}{*}{ Yaş Durumu } & 15-19 Yaş & $0.826^{\star * *}$ \\
\hline & 20-24 Yaş & $1.358^{\star * *}$ \\
\hline & 25-29 Yaş & 0.140 \\
\hline & 30-34 Yaş & $1.450^{* * *}$ \\
\hline & 35-39 Yaş & $1.080^{\star * *}$ \\
\hline & 40-44 Yaş & $0.632^{* * *}$ \\
\hline & 45-49 Yaş & $0.382^{\star *}$ \\
\hline & 50-54 Yaş & $0.296^{\star}$ \\
\hline & 55-59 Yaş & $0.696^{* * *}$ \\
\hline & 60-64 Yaş & 0.252 \\
\hline & 65 Yaş ve üstü & T.S. \\
\hline \multirow[t]{6}{*}{ Eğitim Durumu } & Okul bitirmedi & $1.685^{\star * *}$ \\
\hline & İlkokul mezunu & $0.326^{* * *}$ \\
\hline & Ortaokul mezunu & T.S. \\
\hline & Lise mezunu & $-0.180^{* * *}$ \\
\hline & Yüksekokul/Fakülte mezunu & $0.501^{\star * *}$ \\
\hline & Yüksek Lisans/Doktora mezunu & $0.882^{* * *}$ \\
\hline \multirow[t]{4}{*}{ Medeni Durum } & Evli & $1.172^{* * *}$ \\
\hline & Boşand 1 & $0.563^{\star * *}$ \\
\hline & Eşi öldü & $1.521^{* * *}$ \\
\hline & Bekâr & T.S. \\
\hline \multirow[t]{4}{*}{ Sektör } & İnşaat & $0.642^{* * *}$ \\
\hline & Hizmet & -0.022 \\
\hline & Madencilik/İmalat & T.S. \\
\hline & İşi yok/çalışmıyor & 0.037 \\
\hline
\end{tabular}

Not: ${ }^{* * *} \% 1$ 'de, ${ }^{* * \% 5}$ 'de, ${ }^{*} \% 10$ 'da istatistiki olarak anlamlıdır.

Tablo 6, İstanbul'a göç etme olasılığını veren logit modeldir.15-19, 20-24; 30-34 ile 45-49 yaş aralığında bulunan aktif nüfusun İstanbul'a göç ettiği ve $\mathrm{t}$ istatistiklerinin 25-29 yaş aralığı hariç anlamlı olduğu görülmektedir. Ancak 60-64 yaş ile 65 yaş ve üstünde istatistiki olarak anlamsız çıkmıştır. Dolayısıyla "Büyük kentler genç nüfusu çekmekte, daha yaşlı nüfusu itmektedir" hipotezi desteklenmektedir. Gençler, yaşlılara göre büyük kentlerde yaşamaya eğilimlidirler. ${ }^{44}$ Bireylerin eğitim seviyeleri incelendiğinde eğitim seviyesi arttıkça göreli olarak İstanbul’a göç olasılığının pozitif yönde fakat giderek azaldığı da görülmektedir. Hane halkı büyüklüğündeki artış göç etme olasılığını arttırmaktadır. Erkekler kadınlara göre daha fazla göç etme eğilimindedir. Bireylerin medeni durumlarına bakıldığında tüm kategorilerde t istatistikleri anlamlıdır. Bekârlara göre evlenmiş, boşanmış ve eşini kaybetmiş bireylerin göç etme olasılığı daha fazladır. Çalışmada üzerinde durulan bir değişken bireyin çalıştığı yerin, kuruluş veya işyerinin ana faaliyet kodudur. İnceleme yapıldığında t istatistiği anlamlı çıkan inşaat sektöründe çalışanların göç etme olasılığının daha fazla olduğu görülmüştür. Dolayısıyla, denilebilir ki daha çok vasıfsız ve eğitim düzeyi düşük işgücünün istihdam firsatı bulabildiği bu sektör İstanbul'da giderek büyümekte, inşaat sektörü göçle gelenlere istihdam olanağı sunmaktadır. Bu durum

44 Edward L. Glaeser, “Learning in Cities”, Journal of Urban Economics, 46/2 (1999), s.259. 
beklenen bir sonuçtur. Son on yılda İstanbul'da özellikle inşaat sektörünün gelişmesi ve iş alanı yaratması sonucu bireyler buraya göç etmektedir. Ancak ikili logit model inşaat sektöründe çalışanların nereden göç ettiğini göstermemektedir. Bu detay aşağıdaki çok durumlu logit modelde daha iyi görülecektir.

Tablo 7. Çok Durumlu Logit Model

\begin{tabular}{|c|c|c|c|c|}
\hline Değişken & & $\begin{array}{l}\text { İlden } \\
\text { İstanbul'a } \\
\text { Göç } \\
\text { Edenler }\end{array}$ & $\begin{array}{l}\text { İlçeden } \\
\text { Istanbul'a } \\
\text { Göç } \\
\text { Edenler }\end{array}$ & $\begin{array}{l}\text { Köyden / } \\
\text { Bucaktan } \\
\text { İstanbul'a } \\
\text { Göç Edenler }\end{array}$ \\
\hline Sabit & & $-3.718^{\star \star \star}$ & $-4.613^{\star * *}$ & $-4.921^{\star \star \star}$ \\
\hline $\begin{array}{l}\text { Hane halkı } \\
\text { büyüklüğgü }\end{array}$ & & $-0.217^{\star * *}$ & $0.059^{* * *}$ & $0.304^{* * \star}$ \\
\hline \multirow[t]{2}{*}{ Cinsiyet } & Erkek & 0.104 & $0.116^{\star *}$ & -0.008 \\
\hline & Kadın & T.S. & T.S. & T.S. \\
\hline \multirow[t]{11}{*}{ Yaş Durumu } & 15-19 Yaş & $0.612^{* *}$ & $1.092^{* * *}$ & $0.916^{\star * *}$ \\
\hline & 20-24 Yaş & $1.076^{* * *}$ & $1.754^{* * *}$ & $1.323^{* * *}$ \\
\hline & 25-29 Yaş & -0.321 & 0.331 & 0.279 \\
\hline & 30-34 Yaş & $1.159^{* * *}$ & $1.803^{* * *}$ & $1.413^{\star *}$ \\
\hline & 35-39 Yaş & $0.653^{* * *}$ & $1.479^{* * *}$ & $1.136^{\star * *}$ \\
\hline & 40-44 Yaş & $0.634^{\star *}$ & $0.889^{* * *}$ & $0.524^{\star *}$ \\
\hline & 45-49 Yaş & 0.421 & $0.778^{\star * *}$ & 0.097 \\
\hline & 50-54 Yaş & 0.315 & $0.524^{\star}$ & 0.203 \\
\hline & 55-59 Yaş & $0.806^{* * *}$ & $1.115^{\star * *}$ & 0.243 \\
\hline & 60-64 Yaş & $0.504^{*}$ & 0.457 & -0.232 \\
\hline & 65 Yaş ve üstü & T.S. & T.S. & T.S. \\
\hline \multirow[t]{6}{*}{ Eğitim Durumu } & Okul bitirmedi & $1.289^{* * *}$ & $1.345^{\star * *}$ & $1.956^{* * *}$ \\
\hline & İlkokul mezunu & $0.237^{\star}$ & 0.115 & $0.520^{* * *}$ \\
\hline & Ortaokul mezunu & T.S. & T.S. & T.S. \\
\hline & Lise mezunu & $0.283^{\star * *}$ & 0.022 & $-0.856^{* * *}$ \\
\hline & $\begin{array}{l}\text { Yüksekokul/Fakülte } \\
\text { mezunu }\end{array}$ & $1.274^{\star * \star}$ & $0.603^{* \star *}$ & $-1.092^{\star * *}$ \\
\hline & $\begin{array}{l}\text { Yüksek Lisans/Doktora } \\
\text { mezunu }\end{array}$ & $1.567^{\star * *}$ & $1.034^{* * *}$ & $-1.178^{\star \star \star}$ \\
\hline \multirow[t]{4}{*}{ Medeni Durum } & Evli & $0.959^{* * *}$ & $1.121^{\star * *}$ & $1.448^{\star * *}$ \\
\hline & Boşandı & 0.193 & $0.841^{* * *}$ & -0.013 \\
\hline & Eşi öldü & $1.067^{\star * *}$ & $1.568^{\star * *}$ & $1.851^{\star * *}$ \\
\hline & Bekâr & T.S. & T.S. & T.S. \\
\hline \multirow[t]{4}{*}{ Sektör } & İnşaat & $0.486^{* *}$ & $0.323^{*}$ & $0.895^{\star * *}$ \\
\hline & Hizmet & 0.114 & $0.265^{\star * *}$ & $-0.160^{\star *}$ \\
\hline & Madencilik/İmalat & T.S. & T.S. & T.S. \\
\hline & İşi yok/Çalışmıyor & $0.361^{\star * *}$ & $0.199^{\star *}$ & $-0.306^{* * *}$ \\
\hline
\end{tabular}

Not: ${ }^{* *} \% 11^{\prime d e},{ }^{* *} \% 5$ de, ${ }^{*} \% 10$ 'da istatistiki olarak anlamlıdır.

Tablo 7'de çok durumlu logit model incelendiğinde ilden İstanbul'a göç edenlerde hane halkı büyüklüğü arttıkça göç etme olasılığı azalırken; ilçeden, köyden ve bucak- 
tan İstanbul'a göç olasılığı artmaktadır; t istatistiği de istatistiksel olarak anlamlıdır. Hem il, hem de köy ve bucaktan İstanbul'a gidenlerde cinsiyetin göç üzerinde bir etkisi çıkmamış; ancak ilçede yaşayan erkeklerin kadınlara göre göç etme olasılığının daha fazla olduğu görülmüştür. Aslında, özellikle Türkiye’de 1980 sonrası kadınların göç etmeye yönelik deneyimlerinin artış gösterdiği düşünüldüğünde ${ }^{45}$, önceki dönemlerde daha çok erkek egemen olan göç olgusunun hiç değilse cinsiyetin bir etkisi olmadığını görecek şekilde değişmiş olması, ülkenin göç eğilimi ile nispeten tutarlıdır. Göç edenlerin demografik özelliklerinden medeni duruma bakıldığında, bekârlara göre evli ve eşini kaybetmiş bireylerin genel olarak daha fazla oranda İstanbul'a göç ettikleri görülmüştür.

Çok durumlu logit model'de ilden, ilçeden, köy ve bucaktan İstanbul'a göç edenlerde "büyük kentler genç nüfusu çekmekte yaşlı nüfusu itmektedir hipotezi" burada doğrulanmaktadır (25-29 yaş hariç). Bir diğer ifadeyle; gençler, yaşlllara göre büyük kentlerde yaşamayı tercih etmektedir. Gençlerin yaşlılara göre büyük kentlere göç etmesinin sebebini; kentlerde gençleri cezbeden eğitim ve istihdam olanaklarının daha fazla olması, kentlerin sunduğu öğrenme fırsatlarına gençlerin değer veriyor olması ${ }^{46}$ ile açıklamak mümkündür. Ayrıca, genel nüfus içinde genç nüfusun fazla olmasının Türkiye'deki göç hareketlerinin önemli bir unsuru olduğunu belirten Başel de, kursalda geleneksel geniş aile yapısı içinde olmak istemeyen gençlerin gerek yalnız gerekse eşleriyle birlikte kente doğru göç etme eğilimlerinin olduğunu belirtmektedir. ${ }^{47}$

İlden İstanbul’a göç edenlerde "büyük şehirler eğitimli çalışanları hala çekmektedir" hipotezi de desteklenmektedir (parlak 1şıklar hipotezi). Bu kapsamda, diğer bir ilde yaşamakta olan ancak beşeri sermaye düzeyi gelişmiş ve yüksek gelirli bir iş bulma ihtimali yüksek olan kişilerin daha yüksek gelir elde etme amacıyla göç ettiklerini söylemek mümkün olabilir. Ancak çalışmanın bulgularında, ilçeden, köy ve bucaktan İstanbul'a gelenlerde okuryazar olup okul bitirmemiş olanların daha fazla göç ettikleri görülmüştür. İlçeden üniversite ve daha üstü eğitime sahip olanların göreli olarak daha az, ancak yine de pozitif yönde göç ettikleri çıkmıştır. Köyden İstanbul’a göç eden bireylerin eğitim durumu farklılık göstermektedir. Ortaokul mezunlarına göre okul bitirmemiş ve ilkokul mezunları İstanbul'a daha fazla göç etmekteyken, ileri eğitim düzeylerinde göç etmedikleri bulunmuştur. Bunun bir nedeni, halen köyde kamu kurumlarında çalışmak durumunda olan veya ücretli bireylerin varlığı olabilir. Bir diğer açıklama, İstanbul'da inşaat sektörü gibi vasıfsız işgücüne ihtiyaç duyan sektörlerin genişlemesi ve bu alanın daha çok eğitim düzeyi düşük olan bireylere istihdam olanağı sağlıyor olmasıdır. Nitekim çalışmanın diğer bulgularında da, daha çok inşaat sektöründe çalışanların İstanbul'a göç ettikleri dikkat çekmektedir. Dolayısıyla, kırsalda ücretsiz aile işçisi konumunda olan bireyin kente vasıfsız işgücü olarak eklemlenmesi söz konusu olmaktadır.

Yukarıdaki tüm açıklamalardan sonra, Ek Tablo 1'de alternatiflerin birleştirilebile-

45 Selim, “Türkiye’de Göç Kadınlaşıyor mu?”, s.47.

46 Glaeser, "Learning in Cities", s.4.

47 Halis Başel, “Türkiye’de Nüfus Hareketlerinin ve İç Göçün Nedenleri”, Sosyal Siyaset Konferansları Dergisi, 53 (2007), s.523. 
ceğini söyleyen $\mathrm{H}_{0}$ hipotezinin Likelihood Ratio (LR) ve Wald testi sonuçları verilmiştir. Burada mümkün olan alternatif birleşimleri görülmektedir. Test sonuçları incelendiğinde hem LR hem de Wald testi sonuçlarına göre alternatiflerin birleştirilemeyeceği, yani bağımsız olduğu sonucuna varılmıştır. Ayrıca Ek Tablo 2'de çok durumlu logit modelinde yer alan tüm değişkenlere ilişkin katsayıların sıfıra eşit olduğunu ifade eden $\mathrm{H}_{0}$ hipotezi, LR ve Wald testleri kullanılarak test edilmiştir. Test sonuçlarına göre cinsiyet değişkeni ile yaş değişkenine ait olan 25-29, 50-54 ve 60-64 yaş kategorilerine ait katsayılar istatistiki olarak anlamlı sonuçlar vermemiştir. Bunun yanında diğer değişkenlerin kategorilerine ait tüm katsayılarda istatistiki olarak anlamlı sonuçlar elde edilmiştir.

\section{Sonuç ve Öneriler}

Türkiye'de iç göç hareketi ekonomik olduğu kadar toplumsal yapıyı da etkileyen önemli bir olgudur. Ülkedeki göç genellikle kırdan kente yönelen, ancak son yıllarda kentler arası da yaşanan bir örüntüye sahiptir. Aynı zamanda, hızlı ve düzensiz göç dalgaları, özellikle büyük kentlerde, sağlık, ulaşım, barınma, eğitim ve istihdamda ciddi kentsel sorunlar yaratmaktadır. Yaşanan bu sorunlar nedeniyle, göçe yüklenen anlam da genellikle olumsuz olmuştur. Türkiye'de genel olarak iç göçe ilişkin özellikle 1980'den sonraki veriler incelendiğinde, göçün kentten kente öncelik taşımaya başladığını, kırdan kente göçün hızının azaldığı görülmektedir. İç göçten en fazla etkilenen ve yaşadığı kentsel sorunlarla gündeme gelen İstanbul'a yönelik iç göç bu çalışmanın konusunu oluşturmaktadır. Yapılan veri analiziyle, İstanbul’a göç edenlerin, köy, ilçe ve kent düzeyinde, kim olduğunu, sosyo-demografik faktörler açısından ortaya çıkarmak amaçlanmıştır. Özellikle kişilerin çalıştığı sektör de dikkate alındığında hangi sektörün etkili olduğunu görmek ve incelemek çalışmanın bir diğer amacidır.

1965 sonrası İstanbul'un sanayileşmeye başlaması ile birlikte gelen “emek göçü” niteliğindeki göç, daha çok kırsaldan gelen vasıfsız emek olmaz üzere, eğitim düzeyi yüksek olanları da içermektedir. Sonrasında gelen göç dalgalarında ise, kadın göçü de artış göstermeye başlamış, aile olarak göç edenlerin kalıcı olacakları anlaşılmıştır. 1985 sonrası, son dalga göç hareketi ise taşra kentlerden İstanbul'a doğru olduğu yaşanmıştır. ${ }^{48}$ Dolayısıyla, Türkiye’nin iç göç hareketlerinin önemli destinasyon merkezlerinin başında gelen İstanbul, nüfusunun neredeyse üçte ikisinin İstanbul dışı doğumlu olduğu, Türkiye’nin en kalabalık, en fazla yatırım çeken, maddi ve beşeri sermaye açısından en avantajlı kenti ${ }^{49}$ halindedir. Tüm bu özellikleri nedeniyle, İstanbul’a yönelik yaşanan iç göçün doğası, neden ve sonuçları sosyal bilimler alanında çalışan araştırmacıların ilgi odağıdır. İstanbul'un demografik açıdan hangi kesime göç etmek için daha cazip geldiğinin ortaya çıkarılması, kentsel planlamaların ve ilgili sosyal politika önlemlerinin alınması açısından değerli veriler sunmaktadır.

İstanbul'un göç alma durumuna ilişkin verilerin analiz edildiği bu çalışmanın önem-

48 Özbay ve Yücel, “Türkiye’de Göç Hareketleri”, s.34.

49 Sedat Murat, “Doğum Yerlerine Göre İstanbul Nüfusu ve İç Göçler”, Sosyal Siyaset Konferansları Dergisi, 53 (2007), s.84. 
li bir bulgusu, köyden İstanbul’a göç eden bireylerin eğitim durumunun farklllık gösteriyor olmasıdır. Ortaokul mezunlarına göre okul bitirmemiş ve ilkokul mezunu olanlar İstanbul’a daha fazla göç etmekteyken, ileri eğitim düzeylerindeki bireylerin göç etmedikleri bulunmuştur. Daha önceki yıllara ait bulgular da bu yöndedir. Örneğin, 1965 ve 1970 yılları arasındaki sosyoekonomik açıdan göç hareketlerini inceleyen Tanfer, eğitim ve vasıf açısından kırsal ve kent göçlerinin birbirlerinden farklı olduğunu bulmuştur. Araştırmacı, kırsaldan kentlere daha çok genç, eğitim ve vasıf düzeyi düşük olanların; kentler arası ise göreli daha eğitimli ve vasıflı olan bireylerin göç ettiğini ifade etmektedir. ${ }^{50}$ Türkiye'deki genel göç eğilimini incelediği çalışmasında Dücan da ortaokul düzeyinde gerçekleşen okullaşma oranındaki artışın özellikle şehirden verilen göçü arttırdığ sonucunu elde etmiştir. ${ }^{51}$ Bir diğer ifadeyle eğitimin göç eğilimini arttırması köy için değil, şehir için daha geçerlidir.

Eğitim değişkenine ilişkin bu araştırmanın bulguları, genel olarak Türkiyedeki iç göç eğilimlerine ilişkin diğer araştırma bulgularından farklı bulunmuştur. Filiztekin ve Gökhan tarafından 1999 ve 2000 yıllarındaki nüfus sayımlarına ilişkin verilerin analiz edildiği bir çalışmada, tanımlayıcı istatistiklerle Türkiye içinde göç edenlerin özellikleri anlaşılmaya çalışılmıştır. Bu istatistiklere göre, daha çok gelir arayışı içinde olan, nispeten genç ve daha iyi eğitimli olanların genel nüfusa oranla daha fazla göç etme eğilimi içinde olduğu görülmüştür..$^{52}$ Benzer şekilde, 2002 yllında hane halklarına uygulanan anket ile gerçekleştirilen İzmire yönelik iç göç araştırmasında, eğitimli genç nüfusun göçe etkide bulunduğu görülmüştür. ${ }^{53}$ İstanbula yönelik yaşanan iç göçte eğitimin düşük düzeyde olmasının etkili bir faktör olması, İstanbul’un eğitimli nüfus için artık cazip bir istihdam fırsatı sunamıyor olması ile de açıklanabilir. Nitekim iç göç açısından İstanbul'un şanslı bir kent olmadığı, ülke genelinden gelen vasıfsız bir göçmen kitlesi için çekici olduğu da belirtilmektedir. ${ }^{54}$ Düşük vasıf ve eğitim düzeyleri nedeniyle kırdan kente göç eden kesim, İstanbul'da ancak kayıt dışı sektörde kendine yer edinebilmekte ve İstanbul, kırdan göç etmişlerin kayıt dışı sektörde istihdam edildikleri bir kent konumuna gelmiş olmaktadır. Bu durum, ilden İstanbul’a göç edenlerde farklı şekilde gelişmiş, eğitim düzeyi daha yüksek olanların göçü söz konusu olmuştur. Bulgular Bulutay ve Taştı’nın düşük eğitim düzeyine sahip kırsalda yaşayanların göçünün kayıt dışı sektörde istihdam şansı bulacağına dair açıklamaları ile paralellik göstermektedir. ${ }^{55}$ Ayrıca bu çalışmanın bir diğer bulgusu olan inşaat sektöründe çalışanların İstanbul'a taşınıyor olması da, sektörün eğitim gerektirmemesi nedeniyle, düşük eğitim düzeyinin göç kararı üzerindeki etkisini

50 Koray Tanfer, "Internal Migration in Turkey: Socioeconomic Characteristics by Destination and Type of Move, 1965-70", Studies in Comparative International Development, 18/4 (1983), s.105.

51 Engin Dücan, “Türkiye’de İç Göçün Sosyo-Ekonomik Nedenlerinin Bölgesel Analizi”, Ekonomik ve Sosyal Araştırmalar Dergisi, 12/2 (2016), s.181.

52 Alpay Filiztekin ve Ali Gökhan, “The Determinants of Internal Migration in Turkey”, Paper presented at the International Conference on Policy Modeling, Eco Mod 2008. Berlin, Germany, erişim: 16 Haziran 2018. http:// research.sabanciuniv.edu/11336, s.25.

53 Şenay Üçdoğruk, “İzmir'deki İç Göç Hareketinin Çok Durumlu Logit Teknikle İncelenmesi”, Dokuz Eylül Üniversitesi İİB Dergisi, 17/1 (2002), s.171.

54 Murat, "Doğum Yerlerine Göre İstanbul", s.116.

55 Tuncer Bulutay ve Enver Taştı, "Informal Sector in the Turkish Labor Market", Türkiye Ekonomi Kurumu, Tartışma Metni 2004/22, erişim 21 Eylül, 2018. http://www.tek.org.tr/dosyalar/informal_in_turkey.pdf., s.16. 
açıklamaktadır. İnşaat sektörünün İstanbul için göç kararında önemli bir unsur olması Yürüdür tarafından da dile getirilmiş, araştırma kapsamında Sivas’ın Koyulhisar ilçesinden inşaat sektöründe çalışmak için İstanbul'a mevsimlik göç edilmesinin önemi vurgulanmıştır. ${ }^{56}$

Kişilerin medeni durumlarına bakıldığında; bekârlara göre, evli ve eşini kaybetmiş bireylerin daha fazla göç ettikleri görülmüştür. Daha önce de belirtildiği gibi, bireysel göçten çok ailelerin göçü giderek önem kazanmıştır. 1965’lerde sanayinin gelişmesine bağlı olarak yaşanan, kırsaldan çalışmak için kente doğru, erkek egemen ve yalnız göç eden profilin değişmiş olduğunu, bunun yerine hane halkından birine bağımlı olarak, aile fertlerinin birlikte göçünün ciddi bir orana ${ }^{57}$ sahip olduğunu görmekteyiz. Ayrıca, kadınlarda evlenmenin göç etmenin arkasındaki sebepler arasında ilk sıralarda olması da evlilerin daha fazla göç ediyor olmasında etkili olduğu söylenebilir. ${ }^{58} \mathrm{Bu}$ durum, ülkenin erkek egemen kültürün baskın olmasından kaynaklı, kadının iş bulmak için göç eden erkeğin yanında taşınma biçimindeki evlilik göçü ${ }^{59}$ ile açıklanabilir. Eşini kaybetmiş olanların göç etmesinin ise, sosyal destek açısından göç etmiş diğer akrabalarının yanına taşınma eğiliminden kaynaklanabileceği düşünülmektedir. Çünkü daha önce göç etmiş olan hısım, akraba, arkadaş gibi sosyal ağların varlığı, yani bir önceki dalgada göç etmiş olanların sosyal destek sağlama açısından çekici gücü Türkiye’deki kırdan kente yönelik göçün önemli belirleyicilerindendir. ${ }^{60}$

İstanbul’a yönelik iç göçü analiz etmek için yapılan bu çalışma, özellikle günümüzde kentin iç göçü çekme noktasında dinamiklerinin değiştiği bir zamana denk gelmesi açısından önemlidir. Daha önce de belirtildiği gibi, İstanbul'un eskiden olduğu gibi, göç için çekiciliği azalmakta, halen göç aldığı gibi çok yoğun olarak göç de vermekte ve net göç hızı 2015 yılından itibaren eksi değerlere düşmektedir. Bu düşme eğilimi doğrultusunda, halen İstanbul'a göç edenlerin niteliklerinin sorgulanması, sosyal politika önlemlerinin alınmasını sağlamak açısından değerlidir. Bu çalışma da, İstanbul'a yönelik iç göçün neden ya da sonuçları üzerinde durmak ve bunları belirlemekten ziyade, sosyo-demografik açıdan kimin göç ettiğini anlamaya yöneliktir. İstanbul'a göç eden bireylerin kim olduğunun anlaşılması, bu bireylerin ihtiyaçlarına odaklanan, kentle bütünleşmesinin sağlanması için uyumlu çalı̧̧malar yapmak isteyen yerel yönetimler için yol gösterici olacaktır. Ayrıca çalışma, giderek eğitim ve vasıf düzeyi düşük göçmenler için çekici hale gelen İstanbul'da kentsel yoksulluğun önüne geçmek adına sosyal politika önlemlerinin alınmasına yardımcı olacak veriler de sağlamaktadır. İlaveten, çalışmanın Türkiye’nin göç destinasyonu olan diğer şehirlerini de dikkate alan bir Türkiye iç göç haritası çıkartılarak genişletilebileceği, diğer araştırmalara yol gösterici olabileceği düşünülmektedir.

56 Eren Yürüdür, “Koyulhisar İlçesinde (Sivas) Göç Hareketleri”, Doğu Coğrafya Dergisi, 13/20 (2008), s.32. 57 En güncel veri olan TÜİK, Nüfus ve Konut Araştırması (2011)’na göre hanedeki fertlerden birine bağımlı göç oranı \% 41,5 olup Türkiye'deki en önemli göç nedenidir.

58 Özbay ve Yücel, “Türkiye’de Göç Hareketleri”, s.26.

59 Murat Özgür ve Olgu Aydın, “Türkiye’de Kadın Evlilik Göçü”, Nature Sciences, 5/1 (2010), s.23.

60 Gedik, "Internal Migration”, 171; Mustafa Ercilasun, Ayșen Hiç Gencer ve Özgür Ömer Ersin, “Türkiye’deki İç Göçleri Belirleyen Faktörlerin Modellenmesi”, International Conference on Eurasian Economies 2011, erişim 15 Mayıs, 2019. https://avekon.org/papers/378.pdf, s.323. 


\section{Kaynakça}

Akşit, Bahattin. "İçgöçlerin Nesnel ve Öznel Toplumsal Tarihi Üzerine Gözlemler: Köy Tarafından Bir Bakış” Ahmet İçduygu. Türkiye’de İç Göç. İstanbul: Türkiye Ekonomik ve Toplumsal Tarih Vakfı, 1998.

Bahar, Ozan ve Fehime Korkmaz Bingöl. “Türkiye’de İç Göç Hareketlerinin İstihdam ve İşgücü Piyasalarına Etkileri”. Süleyman Demirel Üniversitesi İktisadi ve İdari Bilimler Fakültesi Dergisi, 15/2 (2010): 43-61.

Bal, Hüseyin, Hasan Hüseyin Aygül, Zekavet Nuran Oğuz ve Meyrem Tuna Uysal. "Göçle Gelenlerin Toplumsal Sorunları (Isparta Örneği)". Süleyman Demirel Üniversitesi Fen-Edebiyat Fakültesi Sosyal Bilimler Dergisi, 27, (2012): 191-210.

Başel, Halis. “Türkiyede Nüfus Hareketlerinin ve İç Göçün Nedenleri”. Sosyal Siyaset Konferansları Dergisi, 53 (2007): 515-542.

Bostan, Hakan. “Türkiye'de İç Göçlerin Toplumsal Yapıda Neden Olduğu Değişimler, Meydana Getirdiği Sorunlar ve Çözüm Önerileri”. Coğrafya Dergisi, 35 (2017): 1-16.

Bulutay, Tuncer ve Enver Taştı. "Informal Sector in the Turkish Labor Market", Türkiye Ekonomi Kurumu, Tartışma Metni 2004/22.Erişim 21 Eylül, 2018. http://www.tek.org.tr/dosyalar/informal_in_turkey.pdf.

Bülbül, Serpil ve Ali Köse. “Türkiye’de Bölgelerarası İç Göç Hareketlerinin Çok Boyutlu Ölçekleme Yöntemi ile İncelenmesi”. İstanbul Üniversitesi İşletme Fakültesi Dergisi, 39 (2010): 75-94.

Çağlayan, Savaş. “Göç Kuramları, Göç ve Göçmen İlişkisi”. Muğla Üniversitesi Sosyal ve Beşeri Bilimler Araştırmaları Dergisi, 17 (2011): 67-91.

Çağlayan, Savaş ve Asiye Kemik. "Kırdan Kente İç Göç Süreciyle Kadınların İş Yaşamına Katılımları ve Sonuçları”. Süleyman Demirel Üniversitesi Fen-Edebiyat Fakültesi Sosyal Bilimler Dergisi, 43 (2018): 143-157.

Çelik, Fatih. "İç Göçlerin İtici ve Çekici Güçler Yaklaşımı ile Analizi”. Erciyes Üniversitesi İktisadi ve İdari Bilimler Fakültesi Dergisi, 27 (2006): 149-170.

Davidson, Russell ve James Gordon MacKinnon. Econometric Theory and Methods. New York: Oxford University Press, 1999.

Dücan, Engin. “Türkiye'de İç Göçün Sosyo-Ekonomik Nedenlerinin Bölgesel Analizi”. Ekonomik ve Sosyal Araştırmalar Dergisi. 12/2 (2016): 167-183.

Ercilasun, Mustafa, Ayşen Hiç Gencer ve Özgür Ömer Ersin. “Türkiye'deki İç Göçleri Belirleyen Faktörlerin Modellenmesi”, International Conference on Eurasian Economies 2011. Erişim 15 May1s, 2019, https://avekon.org/papers/378.pdf.

Filiztekin, Alpay ve Ali Gökhan. "The Determinants of Internal Migration in Turkey”. Paper presented at the International Conference on Policy Modeling, Eco Mod 2008. Berlin, Germany. Erişim 16 Haziran, 2018. http://research.sabanciuniv. edu/ 11336

Gedik, Ayşe. "Internal Migration in Turkey, 1965-1985: Test of Conflicting Findings in the Literature". Review of Urban \& Regional Development Studies, 9/2 (1997): 170-179. 
Glaeser, Edward L. "Learning in Cities”. Journal of Urban Economics. 46/2 (1999): 254-277.

Günay, Enver, Dilek Atılgan ve Emine Serin. "Dünya'da ve Türkiyede Göç Yönetimi”. Kahramanmaraş Sütçü İmam Üniversitesi İktisadi ve İdari Bilimler Fakültesi Dergisi. 7/2 (2017): 37-60.

Gürel, Ali ve Yasemin Balta. “İstanbul'un Göç Olayı ve Etnik Hayat Üzerine”. Marmara Sosyal Araştırmalar Dergisi. 1 (2011): 1-15.

Güreşçi, Ertuğrul. “Ortak ve Farklı Yönleriyle İç ve Dış Göçler”. Journal of International Social Research. 9/43 (2016): 1058-1064.

Hausman, Jerry ve Daniel McFadden. "Specification Tests for the Multinomial Logit Model”.Econometrica. 52/5 (1984): 1219-1240.

Hemmasi, Mohammad ve Carolyn V. Prorok. "Women's migration and quality of life in Turkey".Geoforum. 33 (2002): 399-411.

İçduygu, Ahmet, İbrahim Sirkeci ve İsmail Aydıngün. “Türkiye’de İç Göç ve İçgöçün İşçi Hareketine Etkisi”. Ahmet İçduygu. Türkiye’de İ̧ Göç. İstanbul: Türkiye Ekonomik ve Toplumsal Tarih Vakfı, 1998.

Karpat-Çatalbaş, Gaye ve Ömer Yarar. “Türkiye’deki Bölgeler Arası İç Göçü Etkileyen Faktörlerin Panel Veri Analizi ile Belirlenmesi”. Alphanumeric Journal. 3/1(2015): 99-117.

Kaştan, Yüksel. “Türkiye’de Cumhuriyet Dönemi İç Göç Hareketleri”. Journal of International Socia lResearch. 9/42 (2016): 692-700.

Kentleşme Şurası. "Kentsel Yoksulluk, Göç ve Sosyal Politikalar”. Ankara: T.C. Bayındırlık ve İskân Bakanlığı, 2009.

Levine, Ned ve Sunday Üner. Population Policy Formation and Implementation in Turkey. Ankara: Hacettepe Nüfus Etüdleri Enstitüsü Yayını, 1978.

Long, J. Scott ve Jeremy Freese. Regression Models for Categorical Dependent Variables Using Stata. USA: Stata Press, 2001.

McFadden, Daniel. "Econometric Analysis of Qualitative Response Models". Handbook of Econometrics. Haz., Zvi Griliches ve Michael Intriligator. Amsterdam: Elsevier Science B.V.,1984.

Murat, Sedat. "Doğum Yerlerine Göre İstanbul Nüfusu ve İç Göçler”. Sosyal Siyaset Konferansları Dergisi. 53 (2007): 83-140.

Özbay, Ferhunde ve Banu Yücel. Türkiye’de Göç Hareketleri, Devlet Politikaları ve Demografik Yapı. Nüfus ve Kalkınma: Göç, Eğitim, Demokrasi, Yaşam Kalitesi. Haz., Ferhunde Özbay vd. Ankara: Hacettepe Üniversitesi Nüfus Etütleri Enstitüsü Yayınları, 2001.

Özcan, Deniz Ela. “Çağdaş Göç Teorileri Üzerine Bir Değerlendirme”. İş ve Hayat Dergisi. $2 / 4$ (2017): 183-215.

Özdemir,Dilek. “TürkiyedeBölgelerarasıİçGöçHareketlerinin Belirleyicileri”.Atatürk Üniversitesi Sosyal Bilimler Enstitüsü Dergisi. 22/3(2018): 1337-1349,

Özgür, Murat ve Olgu Aydın. “Türkiye'de Kadın Evlilik Göçü”. Nature Sciences. 5/1 (2010): 18-31. 
Öztürk, Mustafa ve Nihat Altuntepe. "Kentsel Alanlara Göç Edenlerin Kent ve Çalışma Hayatına Uyum Durumları: Bir Alan Araştırması”. Journal of Yasar University. 11/3 (2008): 1587-1625.

Peterson, William. "A General Typology of Migration". American Sociological Review. 23/3 (1958): 256-266.

Sağlam, Serdar. “Türkiyede İç Göç Olgusu ve Kentleşme”. Türkiyat Araştırmaları. Erman Altun Özel Kitaplığı, 5 (2006): 34-44.

Selim, Sibel. "Türkiye’de Göç Kadınlaşıyor mu?:Ekonometrik Bir Analiz" Adnan Menderes Üniversitesi Sosyal Bilimler Enstitüsü Dergisi. 4/3 (2017): 43-63.

Small, Kenneth A. ve Cheng Hsiao. "Multinomial Logit Specification Tests", International Economic Review. 26/3 (1985): 619-627.

Suğur, Nadir, Serap Suğur, Temmuz Gönç-Şavran, Oya Beklan Çetin, "Hizmet Sektöründe Çalışan Yoksulların Geçim Stratejileri ve Sosyal İlişki Ağları: Eskişehir Örneği”. İş, Güç Endüstri İlişkileri ve İnsan Kaynakları Dergisi. 12/1 (2000): 59-84.

Şen, Mustafa. “Türkiyede İç Göçlerin Neden ve Sonuç Kapsamında İncelenmesi”. Çalışma ve Toplum. 1 (2014): 231-256.

Şen, Mustafa. “Trabzon'dan İstanbul'a Göç Edenlerin Sosyo-Ekonomik Analizi”. Çalışma Dünyası Dergisi. $2 / 3$ (2014): 46-61.

Tandoğan, Alaettin. “Türkiye Nüfus Hareketlerinde İstanbul'un Yeri”. Coğrafya Araştırmaları. 1/1 (1989): 135-141.

Tanfer, Koray. "Internal Migration in Turkey: Socioeconomic Characteristics by Destination and Type of Move, 1965-70". Studies in Comparative International Development. 18/4 (1983): 76-111.

Tekeli, İlhan. “Türkiye’de İçgöç Sorunsalı Yeniden Tanımlanma Aşamasına Geldi”. Ahmet İçduygu. Türkiye'de İç Göç. İstanbul: Türkiye Ekonomik ve Toplumsal Tarih Vakfı, 1998.

Tutar, Hüseyin ve Deniz Özyakışır. “TRA2 Bölgesinden İstanbul’a Göç Hareketlerinin Nedenlerine İlişkin Bir Araştırma”. Sosyoloji Konferansları, 47/1 (2013): 31-58.

Üçdoğruk, Şenay. "İzmir'deki İç Göç Hareketinin Çok Durumlu Logit Teknikle İncelenmesi”. Dokuz Eylül Üniversitesi İIBBF Dergisi. 17/1(2002): 157-183.

Yürüdür, Eren. "Koyulhisar İlçesinde (Sivas) Göç Hareketleri”, Doğu Coğrafya Dergisi. 13/20 (2008): 19-34.

Zeytinoğlu, Işık Urla, Ömür T. Özmen, Alev E. Katrinli, Hayat Kabasakal, ve Yasemin Arbak. "Migrant Women in Waged Domestic Work in Turkey". Middle East Report, 29/2(1999): 42-45. 


\section{Ekler}

Ek Tablo 1. Alternatiflerin Birleştirilmesi için LR ve Wald Testi

\begin{tabular}{|l|l|l|l|l|}
\hline \multicolumn{2}{|l|}{ Alternatifler } & s.d. & LR Testi - chi2 & $\begin{array}{l}\text { Wald Testi }- \\
\text { chi2 }\end{array}$ \\
\hline İlden & İlçeden & 23 & $202.267^{* * *}$ & $192.0696^{* * *}$ \\
\hline İlden & Köy-Bucak & 23 & $1427.408^{* * *}$ & $1002.317^{* * *}$ \\
\hline İlden & Göç etmemiş & 23 & $789.087^{* * *}$ & $717.084^{* * *}$ \\
\hline İlçeden & Köy-Bucak & 23 & $874.557^{* * *}$ & $677.725^{* * *}$ \\
\hline İlçeden & Göç etmemiş & 23 & $752.272^{* * *}$ & $718.245^{* * *}$ \\
\hline Köy-Bucak & Göç etmiş & 23 & $2306.754^{* * *}$ & $1786.812^{* * *}$ \\
\hline
\end{tabular}

Not: ${ }^{* * *} \% 1$ 'de, ${ }^{* \star} \% 5$ 'de, ${ }^{\star} \% 10$ 'da istatistiki olarak anlamlıdır. s.d., serbestlik derecesini göstermektedir.

Ek Tablo 2. Açıklayıcı Değişkenler İçin LR ve Wald Testi

\begin{tabular}{|c|c|c|c|c|}
\hline Değişken & & s.d. & LR (chi2) & Wald (chi2) \\
\hline $\begin{array}{l}\text { Hane halkı } \\
\text { büyüklüğü }\end{array}$ & & 3 & $454.322^{\star * *}$ & $430.834^{\star * *}$ \\
\hline \multirow[t]{2}{*}{ Cinsiyet } & Erkek & 3 & 5.433 & 5.428 \\
\hline & Kadın & T.S. & T.S. & T.S. \\
\hline \multirow[t]{11}{*}{ Yaş Durumu } & 15-19 Yaş & 3 & $26.928^{* * *}$ & $24.451^{\star * *}$ \\
\hline & 20-24 Yaş & 3 & $77.415^{\star * *}$ & $65.006^{* * *}$ \\
\hline & 25-29 Yaş & 3 & 3.196 & 3.173 \\
\hline & 30-34 Yaş & 3 & $91.613^{* * *}$ & $75.684^{\star * *}$ \\
\hline & 35-39 Yaş & 3 & $54.873^{\star * *}$ & $45.6740^{\star * *}$ \\
\hline & 40-44 Yaş & 3 & $17.901^{\star * *}$ & $16.181^{\star * \star}$ \\
\hline & 45-49 Yaş & 3 & $9.820^{* *}$ & $78.731^{\star *}$ \\
\hline & 50-54 Yaş & 3 & 4.271 & 4.057 \\
\hline & 55-59 Yaş & 3 & $22.464^{* * *}$ & $19.872^{\star * *}$ \\
\hline & 60-64 Yaş & 3 & $5.864^{*}$ & 5.640 \\
\hline & 65 Yaş ve üstü & T.S. & T.S. & T.S. \\
\hline \multirow{6}{*}{$\begin{array}{l}\text { Eğitim } \\
\text { Durumu }\end{array}$} & Okul bitirmedi & 3 & $409.961^{\star * *}$ & $395.191^{\star * *}$ \\
\hline & İlkokul mezunu & 3 & $33.981^{\star * *}$ & $33.554^{* * *}$ \\
\hline & Ortaokul mezunu & T.S. & T.S. & T.S. \\
\hline & Lise mezunu & 3 & $86.848^{\star * *}$ & $81.148^{\star * \star}$ \\
\hline & $\begin{array}{l}\text { Yüksekokul/Fakülte } \\
\text { mezunu }\end{array}$ & 3 & $279.428^{\star * *}$ & $246.616^{\star * *}$ \\
\hline & $\begin{array}{l}\text { Yüksek Lisans/Doktora } \\
\text { mezunu }\end{array}$ & 3 & $107.591^{* * *}$ & $107.122^{* * *}$ \\
\hline \multirow[t]{4}{*}{ Medeni Durum } & Evli & 3 & $479.860^{* * *}$ & $445.463^{\star * *}$ \\
\hline & Boşand 1 & 3 & $22.822^{\star \star \star}$ & $25.824^{* * *}$ \\
\hline & Eşi öldü & 3 & $97.956^{\star * *}$ & $103.439^{\star * *}$ \\
\hline & Bekâr & T.S. & T.S. & T.S. \\
\hline
\end{tabular}


HAMDi EMEÇ / ŞENAY ÜÇDOĞRUK BİRECIKLI / BURCU KÜMBÜL GÜLER

\begin{tabular}{|l|l|l|l|l|}
\hline \multirow{3}{*}{ Sektör } & İnşaat & 3 & $38.430^{\star * *}$ & $39.573^{\star * *}$ \\
\cline { 2 - 5 } & Hizmet & 3 & $18.561^{\star * *}$ & $18.085^{* * *}$ \\
\cline { 2 - 5 } & Madencilik/İmalat & T.S. & T.S. & T.S. \\
\hline & İşi yok/Çalışmiyor & 3 & $26.927^{\star * *}$ & 26.608 \\
\hline
\end{tabular}

Not: ${ }^{\star * \star} \% 1$ 'de, ${ }^{\star \star} \% 5$ 'de, ${ }^{\star} \% 10$ 'da istatistiki olarak anlamlıdır. s.d., serbestlik derecesini göstermektedir. 
İNSAN\&İNSAN, Y11/Year 6, Sayı/Issue 22, Güz/Fall 2019, 785-808

DOI: https://doi.org/10.29224/insanveinsan.485198

\title{
Econometric Analysis of Internal Migration Movements towards İstanbul
}

\author{
HAMDI EMEÇ / ŞENAY ÜÇDOĞRUK BİRECIKLİ / BURCU KÜMBÜL GÜLER
}

\begin{abstract}
Istanbul has been focus of research interest since the city has the most dense population of Turkey as an attractive city for migration. The aim of the study is to find out who migrates to Istanbul in terms of socio-demographical factors on rural, district and urban levels. Data set of this study was drawn from Nomenclature of Territorial Units for Statistics in Turkish Workforce Survey 2015. For the migration model, first binomial logit (individual migrated/not migrated); then multinomial logit model were applied. Having migrated to Istanbul within last ten years is the dependent variable. There are four categories; migration from urban, from district, from rural and not migrated. "Large cities pull younger people, push older people" hypotheses was confirmed with the results of binomial logit model. The results also reveal that workers from the construction sector are more inclined to migrate. Moreover, as education level increases the probability of migration to Istanbul is positively but decreasingly affected.
\end{abstract}

Keywords: Internal migration, Istanbul, Logit model, Multinomial logit model. 